\section{（抄 録）}

\section{障害児の眼鏡装用状況について}

上吉川昌江・林 京子（香川県身体障害者総 合リハビリテーションセンター訓練科 視能訓 練室） 目的：障害児には，遠視，乱視などの 屈折異常が高頻度に合併することは，よく知ら れている。その治療の第一歩は眼鏡をいかにス ムーズに装用させるかである。装用前に母親は, 患児の自覚的訴えがそしいことや，転倒，打撲 による怪我を懸念して眼鏡の作製に不安を示す ことが多い。今回我々は当センター眼科で処方 を行った障害児の眼鏡装用の可能性とその特徵 について検討を行ったので報告する。

対象：対象はH. 1 年10月〜H.6 年 9 月までに 眼鏡処方を行った障害児134例である。年龄は 2 歳〜17歳, 平均 7 歳である。134例の障害の疾患 別の内訳は脳性麻㾇などの中枢神経系異常が64 例, 発達遅滞34例, ダウン症などの先天異常が 26例，その他10例である。

方法：処方は調節麻疸荗点眼による他覚的屈 折検査後, 自覚的視力検查さらに数回の装用練 習を行って製作する。製作後，母親への装用指 導や視覚刺激を行う固視訓練を実施している。 調查は製作後 1 力月毎に装用時間，時間帯につ いて行った。

結果：全体の装用状況は終日装用可能例は $57 \%$, 部分的装用（約 6 時間）可能例は $27 \%$, 装用不可能例は $7 \%$ であった。処方後，経過観 察を行えなかった症例は $9 \%$ あっった。部分的 装用可能例では $83 \%$ 学校，通園施設で装用可 能であった。装用できるまでの期間は終日可能 例は平均 5 力月, 部分的装用例は平均 3 力月で あった。患者別の装用状況では装用不可能例は 先天異常例が多かった。装用による危険性とし てフレームによる眼瞼の怪我が $7 \%$ ，眼鏡の紛 失が $8 \% に$ 認められた。

結論：障害児の眼鏡装用は終日，部分的をあ わせて $84 \% に$ 可能であった。今回，症例に合わ せたレンズ，フレームの選定や，作製前後の装 用練習によって母親の不安感の軽減をはかった ことも奏効の一因と考える。その特徵は眼鏡に
慣れるための試行期間を要すること，時間帯を 学校生活に合わせて習慣化させることが装用の 導入のために有効であることがわかった。

質問 湖崎 克（湖崎眼科）何 D以上の屈 折度から，眼鏡を必要と考えられますか？

答弁 原則的には，健常児と同様と考えてい ます。症例により異なりますが，乱視では 2 〜 $2.5 \mathrm{D}$ 以上, 遠視では $3 \mathrm{D}$ 以上, 近視の場合は裸 眼と矯正の差で装用の有無を考えています。内 斜視のある場合は, 経度の遠視でも眼鏡の必要 があります。

質問 調 廣子（神戸大学） 部分的装用で あった理由は何ですか？

答弁 学校, 通園のみの装用例は, 学校で見 にくいから装用するというのではなく，登校時 〜下校時の時間だけは装用でき，家に帰ると制 服と一緒にはずしてしまうという例です。母親 にもその理由は不明です。その他, 重度の症例 では車椅子，座位時のみ部分的装用となってい ます。

質問 松本富美子（近畿大学）知的障害を 伴う患者に眼鏡を装用させる場合，他覚的にそ の効果を評価する方法があれば教えて下さい。

答弁 固視, 追従の改善とXTの出現頻度の 減少が認められました。“ST. OT”の訓練で絵 カードやコンピューターの画面をよく見るよう になりました。

\section{不同視弱視の立体視と空間周波数特性}

\section{大賀るり・岩本英子・難波美江・古嶋正俊 · 今泉雅資・中塚和夫（大分医科大学眼科）}

目的：弱視治療においては，視力の向上が即 両眼視機能の獲得を意味し得ない。健眼と同等 の視力が得られても良好な立体視が得られない 症例や，逆に正常視力に満たなくても良好な立 体視を示す症例がある。今回我々は空間周波数 特性 (Modulation Transfer Function, MTF) がこれらの症例ではどのような特性を示すかを 知る目的で適用し，その成績を検討した。

対象および方法：対象は当科弱視外来で治療 経過観察中の不同視弱視14名28眼（年齢 4 12 歳）で，全例中心固視を確認し，微小角斜視弱 視は除外した。正常視力は矯正視力 1.0 以上，立 
体視はTitmus stereo test（T.S. T) で100sec.以 上, かつTNOで $120 \mathrm{sec}$. 以上と定義した。MTF の測定はMCT8000を用い, 完全矯正下にDAY VISIONに設定して行った。

結果：正常な立体視が得られた症例では, 視 力（治療にて0.6以上となっている）に関わらず 弱視眼のMTFは健眼のそれとほぼ同等, もしく は全体的に感度低下がみられるものの, 中間周 波数域に感度のピークをもつ, いわゆるband pass型を示した。正常な立体視が得られなかっ た症例では中間〜高周波数域で感度の低下した low pass型のMTFがみられた。

結論 : 不同視弱視のMTFは立体視機能の有無

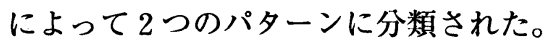

質問 三宅三平（眼科三宅病院） 私の体験 では, 弱視におけるMTFの変化は, 単に視力值 と関係しているだけとの印象です（つまり, 視 力値は悪くなるにしたがい高周波数側から徐々 に低周波数側に向かいcontrast sensitivityが低 下する）が，単に視力值との相関とは考えられ ませんか?

追加 内海 隆（大阪医大） - 不同視弱視と 判断しても, 視力, 立体視の改善が不完全な場 合, 事後振り返って微小角斜視と考えるべき場 合がままあります。示されたcaseの中にもこの ような例があるように見受けられます。ご配虑 なさればよいかと存じます。

\section{MTI photoscreener ${ }^{\circledR}$ 内斜視患者への応用}

\section{庄司倫子・青木 繁・藤山由紀子・新井田孝} 裕・向野和雄 (北里大学 医療衛生学部)

目的：MTI photoscreener ${ }^{\circledR}$ (以下MTI) を用 いた乳幼児の眼位および屈折異常のスクリーニ ング検査は, 最近本邦でも使われ始めいくつか の報告がある。しかし, 斜視患者において調節 要素を含んだ検査目的での応用は，まだ少ない ようである。そこで, 内斜視患者にプラスレン ズを負荷することにより, 眼位の変化と睲孔径 の変化に注目し, 調節因子の評価としての有用 性と臨床的応用について検討を行ったので報告 する。

対象：当院眼科を受診し, 内斜視と診断され 経過観察が行われている症例である。
方法：被検者は, まず非調節麻痺下, 屈折非 矯正下でMTI測定を行なう。次いで, 調節麻痺 剂を用いた屈折検査の結果得られた屈折度のレ ンズ（主にプラスレンズ）を装用させ，写真撮 影を行う。被検者の屈折, 眼位, 調節等の詳緇 な眼科学的検查の結果とMTIの結果を比較し, 調節による眼位と睲孔径の変化について調べた。

結果：ほほ完全矯正下でのレンズ装用により, 眼位が改善している症例では, 瞳孔径の散大が 認められた。レンズ装用によっても眼位に変化 をきたさないものでは瞳孔径に変化は認められ なかった。

結論：MTIの撮影距離が，1 mであるため多 少の調節の影響は考えられるが，眼位が良好に なった症例において睲孔径の変化まで同時に観 察することが出来た。以上のことより従来MTI は, レンズ装用下での応用は期待されていなか ったが，今回内斜視患者にプラスレンズ装用下 で用い, 調節性内斜視, 部分調節性内斜視, 非 調節性内斜視の簡便な鑑別する検查法に成りう るものと考えられた。

質問 矢ヶ竘悌司（眼科やがさき医院） 眼 鏡装用上では凸レンズの拡大効果がでると思い ますが，どのように補正されたのでしょうか。 また, 曈孔径は横径, 縦径いずれを用いたので しょうか。

答弁 瞳孔径の計測は，固視眼の下眼瞼に装 着した目盛りをもとに，写真上で判定しました。 凸レンズによる影響は, 目盛りの应大と角膜径 の拡大の比率の両面から計測し, 横径で計測い たしました。

質問 内海 隆（大阪医大）裸視視力の良 い遠視例で睹孔拡大効果がみられないという調 節性内斜視との差異は, 調節性内斜視のメカニ ズムを考えさせるひとつのヒントになるかと思 いますが，演者のお考えをお教えください。

答弁 遠視例に関しては, 非常に症例数は少 ないが，今回は瞳孔径に屈折矯正による変化は みられませんでした。遠視眼の裸視視力は, 調 節性内斜視と同様に良好であり, 調節力は正常 であると考えられるが, 非矯正時の瞳孔径が小 さくなるということはありませんでした。調節 性内斜視では, 近見反応のトライアッド（調節 
輻輳 縮瞳）が完全に平行していると考えられ るが，遠視眼では両眼視を保ために，輻輳，縮 瞳がおこりにくいためと考えられます。

\section{両眼単一視時の視力測定について 一試作スライドを用いて (第一報) 一}

高木満里子・堀田明弘・根木 昭（熊本大学 医学部眼科学教室) 馬場裕行 - 冨士登謙司（馬 場眼科） 目的：弱視の視機能検查では視力検 査が最もよく使われている。その視力検査は片 眼を覆い一眼ずつ測定する片眼視力で代表され る。しかし，弱視治療後視力が向上しても両眼 視機能は視力值と相関しないことが多い。そこ で，弱視眼にかかっている抑制を定量的に測定 する方法として，ビノキュラーセパNT-3000を 用いて両眼単一視時の片眼視力測定 (両眼単一 視力）を行うための視標スライドを試作した。 今回その有用性を検討したので報告する。

対象および方法：器質的疾患がなく矯正視力 1.0 以上の 6 才から 16 才までの74例 148 眼を正常 対象とした。病的対照には10才から16才までの 4 例 8 眼で, 調節性内斜視 1 例, 不同視弱視 3 例を対象とした。ビノキュラーセパNT-3000を 用いて, 両眼単一視を保ちながら片眼視力測定 を行うための視標，ランドルト環視標スライド を作成した。両眼単一視を確認する目的で視角 6.6度のサークルの中にランドルト環視標を組み 込み，視標は，0.1，0.2，0.3，0.4，0.5，0.6，0.7， $0.8 ， 0.9 ， 1.0$ とした。検查距離 $1 \mathrm{~m}$ ，視標のコ ントラストは $90 \%$ 以上，検査時の室内照度は 101uxとした。さらに従来の方法での遠見視力 と，立体視検査はTitmus stereo test（TST）施 行した。

結果：正常対象群148眼中124眼（83.4\%）は, 両眼単一視力 1.0 を示した。立体視は $40 ”$ から $60 ”$ であった。24眼（16.6\%）は，両眼単一視

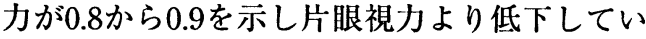
た。両眼とも低下した症例は 6 例，片眼のみは, 12例であった。立体視は，40”から80”を示し た。不同視弱視 3 例のうち 2 例は両眼単一視力 のほうがわずかに低下していた。しかし，1例 は両眼単一視力が (0.8) と片眼視力（0.4）を上 回り，立体視は140”を示した。調節性内斜視
1 例は両眼単一視力において 1 眼が低下した。

結論：正常群は83.4\%において，両眼単一視 力は1.0を示した。低下しても0.8であり，弱視症 例に対して臨床応用できると思われた。

質問 不二門 尚（大阪大学） Binocular sepaを用いた片眼視力の測定は行ったか？

答弁 数症例を行った結果, 通常の片眼視力 と一致しました。今回, 全症例は施行しており ません。

質問 矢ヶ㟝悌司（眼科やがさき医院） $\mathrm{PDH}$ 欠点は，ディスクが回転することによる コントラストの低下がありますが，視力結果に ついてコントラストの影響を考慮されたのでし ょうか？むしろ，MTFと比較した方が興味ある 結果がでると思いますが。

答弁 視標のコントラストは，投影さえた時 の状態が $90 \%$ 以上を示すように条件を整えてお ります。両眼視の状態を確認した時の単眼視力 を測定し，健眼からの抑制を視力值として評価 する事を目的としておりますが，このBinocular sepaは光量を調節することも可能なので，その 点について検討することもおもしろいとおもい ます。ありがとうございます。

小児のロービジョンケアに際して

小松美保 - 大瀧亜季（岩手医科大学視能訓練 室）飯塚和彦・長谷川 豊・田澤 豊（岩手医 科大学眼科学教室） 目的：低視力览のロービ ジョンケアにおいては, 成人の場合と異なって 意思の疎通が図りにくいため, 要望の把握や心 理面などの点で問題が生じることも少なくない。 そこで今回，小児に対するロービジョンケアを 行う際には，何が重要であるかについて検討し た。

対象及び方法：ロービジョンケアが必要と考 えられた $4 \sim 15$ 歳, 視力0.1 0.3の小児 15 例を対 象とした。問診と残存視機能評価の後, 従来か らの成人ロービジョンケア用のチェックリスト を用いて患者の要望を聴取した。その上で，視 覚的補助具 (補助具) の選定と, それによる訓 練を行い，貸出を経て補助具を処方した。その 後，1）要望の把握状況，2）補助具によって quality of life（QOL）が向上したか，3）補助 
具の使用状況，について調査した。

結果：患児の要望を十分に把握することは困 難であり，家族などからの情報提供を要した。 患児が自覚している要望を聴取できたものは 15 例中 8 例であった。また, 残りの 7 例のうち, 患児がこれまで自覚していなかった潜在的な要 望を引き出せたものが 2 例あった。要望を把握 できた 10 例中 9 例に補助具を処方したところ， 全例でQOLが向上した。この 9 例のうち，小学 校低学年以前にケアを始めた 4 例は，全例学校 生活での活用が可能であったのに対し，小学校 中学年以降に開始した 5 例中 4 例は，周囲を気 にして学校での使用を嫌がり家庭内でのみ使用 していた。

考按：低視力児のQOLを向上させるために は，要望を明確にすることが重要であり，その ためには，家族や学校関係者など，周囲の人々 からも情報を提供してもらえる小児用の具体的 なチェックリストを作成する必要があると思わ れた。また補助具の使用は, 小児の心理発達を 考慮して, 羞恥心の少ない小学校低学年までに 早期導入し，習慣づけておくことが望ましいと 考えられた。

質問・追加 三輪まり枝（国立身体障害者り ハビリセンター眼科） 1 ，ロービジョンケア を行う際に成人用チェックリストを用いて補助 具の選定を行っておられるが, 小児用チェック リストの具体的な内容を教えていただきたい。

2. 私共のロービジョン・クリニックにおい ては，学校関係者との連絡をとるにあたっては, 学校で使用している「連絡ノート」を活用して いる。そのノートに医学的な事, 補助具の選定 内容を記載し, 保護者を通して学校側に知らせ, また，学校での使用状況を教えてもらうのに役 立っている。

答弁 1. 追加スライドにお示ししました様 に，今回小児や家族, 教育関係者から聴取でき た要望を参考に，一般の眼科医療機関でも対応 可能なケアを導入する際の目安となるものを考 虑して, 小览のロービジョンケアを行う上での 小児用チェックリストを試作しました。要望を 聴取する際の具体的なキーワードを掲げ，医療 関係者だけでなく周囲からも観察してもらえる
ような項目を設けました。

2. ご追加ありがとうございます。現在試案 中の小児用チェックリストに加えて, 教育関係 者や家族との連絡ノート等も取り入れて，より 良いコミュニケーションを図っていければと思 います。

質問 杉谷 邦子（東京都医療公社 東京地 域病院）病院という限られた場で，障害をも つ子供と補助具の十分な使用に至るまでの関係 を作っていくのは難しい。日常子供に接する親 への指導の重要性を痛感しているが, 何か親へ 働きかけをされていたらお教え下さい。

答弁 当科では, 小児のロービジョンケアを 週 1 回午後に 1 名 $/ 2 \sim 3$ 時間の枠で行ってお ります。精神発達遅延やその他の理由でケアの 導入を円滑に運べない症例に対する対応は, 今 現在のところ (1)視機能の評価（2)小児の生活, 学習状況の把握 (3)補助具全般の説明と関連機 関の情報提供などに留まっています。

\section{岩手県立磐井病院における}

ロービジョン・ケア

佐渡一成・舘 雅貴・荒木ひろ美・橘 信彦 (岩手県磐井病院 眼科) 金井 淳（順天堂大 学 眼科) 目的：日常の眼科外来において視 機能回復の可能性の低い患者は少なくない。こ のような視覚障害者の方々に対するリハビリテ ーションは重要であり, 視能訓練士や眼科医の 役割は大きい。視覚障害者リハビリテーション の手段の 1 つにロービジョン・ケアがあり, 適 切な視覚補助具の処方と使用訓練より視機能障 害による不利を多くの場合軽減できる。そこで 今回当院におけるロービジョン・ケアの現状を まとめ問題点を含め考察する。

対象および方法：岩手県立磐井病院で31ヶ月 間にロービジョン・ケアを行った61例について 視機能・補助具の処方状態などについて検討し た。

結果 : 視力・視野障害に対するロービジョ ン・ケア52例（網脈絡膜萎縮14例 緑内障 10 例 糖尿病網膜症が 9 例など 優位眼の視力：指数 弁〜0.6）中45例に何らかの視覚補助具を処方し た。羞明に対するケアでは16例中14例に遮光眼 
鏡を処方した。補助具の使用により独力で新聞 が読めるようになったなど日常生活で他人の手 助けを借りる事が少なくなり, 精神的にも負担 が減少したそうである。

結論：視覚障害者のリハビリテーションは症 例毎に時間がかかり保険点数上も冷遇されてい るため一般の眼科医療機関では敬遠されがちで ある。しかし眼科医療において非常に重要な問 題であり, 比較的簡便な方法で多くの視覚障害 者の満足が得られることもあり今後さらに積極 的な対応・普及が望まれる。

質問 菅野和子（国立身体障害者リハビリテ ーションセンター）補助具を選定する際に, 治療に期待をかけている患者さんの中には, 補 助具に興味を示さない人があります。先生の患 者さん達はスムーズに補助具へと移行されまし たか。

答弁 当院においてはうまくいっていると思 う。リハビリテーションの窓口となるべき眼科 で適切な告知とその後のケアもある程度行えて いるからだと考えている。告知をされないまま リハビリテーションまで無駄に多くの時間を費 やす方々も多く, リハビリテーションの空口に もなる眼科の役割は重要である。

\section{若年成人と老年成人の眼軸長の比較}

浜野浩司（秋田大学医学部眼科学教室）

目的：近年, 学童および若年成人の近視は, 増加傾向にある。近視が生じる後天性環境要因 の一つとして近業の増加などが考えられている が, 世代間の眼球構造の変化から, 若年者の近 視傾向を論じた研究は少ない。本研究では若年 成人と老年成人の眼軸長, 角膜屈折率を比較す ることで, 若年成人の近視傾向の原因を検討し た。

方法：20～39才までの医学部学生を含む86人 170 眼と， 56 才〜 75 才までの白内障患者を含む 61 人 101 眼の屈折率, 角膜屈折率, 眼軸長を測定 し，その值を統計処理し検討した。

結果と結論：若年成人群（YA群）の眼軸長 は25.02 $\pm 1.40 \mathrm{~mm}$ (平均士標準偏差), 一方, 老 年成人群 $(\mathrm{OA}$ 群) の眼軸長は $23.78 \pm 1.88 \mathrm{~mm}$ と，両者に有意な差が認められた。また，YA
群の角膜屈折率は $43.05 \pm 1.31 \mathrm{D}, \mathrm{OA}$ 群の角膜屈 折率は $44.40 \pm 1.70 \mathrm{D}$ と両者に有意な差が認めら れた。YA群において, 実際の屈折率と角膜屈 折率から算出される屈折率, および, 眼軸長か ら算出される屈折率を取ってみると, 前者にお いてはほとんど相関が認められなかったものの, 後者には強い相関が認められ, 若年成人の近視 要因は眼軸長の増加によることが示された。ま た, 眼軸長のうち, 角膜から水晶体までの距離 (AD)，水晶体前面から後面までの距離 (LD), 水晶体後面から網膜までの距離（VD）を, YA 群とOA群で比較したところ, ADとVDはYA群 で有意に長く, LDはOA群で有意に長かった。 しかし, YA群とOA群との間で, $\mathrm{AD} \pm \mathrm{LD}$ 差 はあまりなく，VDは非常に大きな差を認めた。 このことからYA群の眼軸長の増加は, 主にVD の増加に負うところが大きいものと思われた。 また, 身長と眼軸長との間にはYA群, OA群と もに，弱い正の相関が認められた。

若年成人の眼球は, 老年成人のそれょりも角 膜曲率半径や眼軸長が増加し全体的に大きくな っているが, 若年成人眼の近視化は, 硝子体部 分の長さの増加が主な原因になっていると考え られた。

質問 吉田紳一郎 (独協医科大学越谷病院) 1. 対象とした症例の測定前の屈折值と眼軸長 の関係について

2. 身長と眼軸長に相関がみられたとのご発 表でしたが, 欧米人（外国人）では身長が高い にもかかわらず，眼軸長との相関はないものと 推測されますが，いかがでしょうか。

答弁 1 . 若年成人および老年成人の雨群に おいて, 眼屈折率と眼軸長の間には極めて有意 な正の相関が認められましたが，眼屈折率と角 膜屈折率，および角膜屈折率と眼軸長の間には 有意な相関関係は認められませんでした。これ らのことから，眼屈折率は主に眼軸長に依存し ていることが示唆されました。

2. 欧米の論文を散見したところ，欧米人の 眼軸長が長いという報告はなく，例えば，アメ リカ人の眼軸長の平均值は, $23.5 \mathrm{~mm}$ であるとい う報告もあります。しかし，今回発表した日本 人の二つの世代間では，身長で $10 \mathrm{~cm}$ 以上もの増 
加が認められ，同一民族内でこれだけ急激に身 長が伸びたケースは珍しいと思われます。現在 のところ，日本人の若年世代で眼軸長が伸びて いる理由は，栄養状態の改善などに伴う体格の 変化によるのか, 生活環境の変化によるのか, あるいはその他の要因によるのか分かっており ませんが，もし，体格の変化が眼軸長の増加の 要因の一つであるならば，身長と眼軸長の間に 正の相関が認められてもおかしくないのではな いかと考えられます。

追加 内海 隆（大阪医大） 全身的因子 （身長や年齢）と比較する際には，両眼の值を 抽出するのではなく, randomに片眼值をサンプ リングするのが通常の手法です。今後のご発展 の参考にして頂ければよいかと存じます。

答弁 ありがとうございます。原著作成など の際には是非参考にさせていただきます。

\section{Polarized Four-Dot Testを用いた融像検査 と抑制暗点測定}

高 信珊・川添美穂子・矢ヶ㟝悌司（眼科や がさき医院） 目的：Polarzed Four-Dot Test （P4D test）はWorth Four-Dot Test（W4D test）が赤緑眼鏡を用いて両眼分離するのに対 し，P4D testは偏光フィルターを用いて両眼分 離を行うため，W4D testより自然視に近い状態 で両眼視機能検査を行うことができる。今回 我々もP4D testを試作し，その有用性を検討す るとともに抑制暗点の大きさの測定を試みたの で報告する。

方法：P4D testの測定可能な年齢を検討する ために正常児53例（2歳 1 か月〜 5 歳11か月） についてP4D testを行い, その成功率について 検討を行った。次に, 不同視弱視症例，微小斜 視を含む斜視症例，合計47例を対象として， P4D test, W4D test, Bagolini線条レンズ検査 （BAG）を行って融像の有無について検討を行 った。最後に微小内斜視 1 例を対象として, P4D testの測定距離を連続的に変えながら抑制 暗点の大きさを測定し，位相差ハプロスコープ (PDH) で測定した抑制暗点の大きさと比較検 討を行った。

結果：P4D testは 3 歳から検査可能で, 正常
児で 3 歳 6 か月以降では34例中32例 $(94.1 \%)$ の検查成功率を示した。不同視弱視，斜視症例 を対象した融像検査では，BAGを基準とした抑 制の感受性および特異性は, P4D testでは近見 で89.5\%，89.7\%，遠見で83.9\%，87.5\%，W4D testでは近見で $81.8 \% ， 96.0 \% ，$ 遠見で79.4\%， 92.3\%とほほ相違はなかったが，偽陽性率は， P4D testでは近見で10.5\%，遠見で16.1\%，W4D testでは近見で $18.2 \%$ ，遠見で $20.1 \%$ と $4 \mathrm{D}$ test の方がより自然視に近い状態で抑制の有無の判 定が可能と思われた。抑制暗点は，P4D testで 測定された大きさとPDHで測定された大きさと 非常に近似しており，P4D testよる抑制喑点の 大きさの測定が可能と思われた。

結論：P4D testは自然視に近い状態で融像， 抑制検查が可能であり，測定距離を連続的に変 えることにより抑制暗点の大きさの測定も容易 に行いえる検査と考えられ，臨床応用の可能性 の高い検査方法と思われた。

質問 不二門 尚 (大阪大学) 1.3才未 満の子供が測定困難なのは，数が言えないため か。

2. Bagolini SG testを融像の検査の基準とし て用いた理由。

答弁 1.P4D test, 光の数の変化だけ答え るので，低年齢でも測定が可能と思われます。 3 歳末满の子供が数を 4 まで数えられないので, 測定困難と今回の実験で証明されました。

2. 今回, 中心融像を検討する目的で, Bagolini SG testを用いました。

\section{弱視治療中に眼瞼および睫毛に色素異常を 来した 1 例}

柳田ひとみ・中川真紀（帝京大学医学部眼科 学教室） 目的：弱視治療における遮閉法の副 作用として今回私達は，遮閉具と硫酸アトロピ ンを用いた弱視訓練中に，健眼の眼瞼皮䖉およ び睫毛の色素脱出がみられた症例を経験したの で報告する。

症例および経過：症例は 6 歳男児。他院にて 左眼の弱視治療を行っていたが，転居のため帝 京大学病院眼科を受診した。初診時, 両眼とも に中心固視，視力 $\mathrm{Vd}=(0.7) \mathrm{Vs}=(0.9)$ であっ 


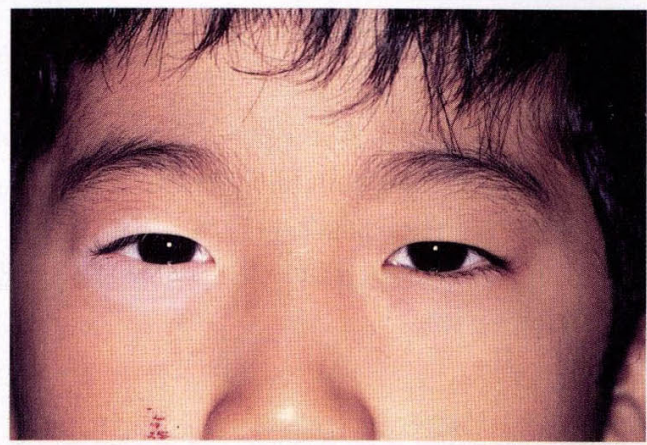

1. 弱視訓練後
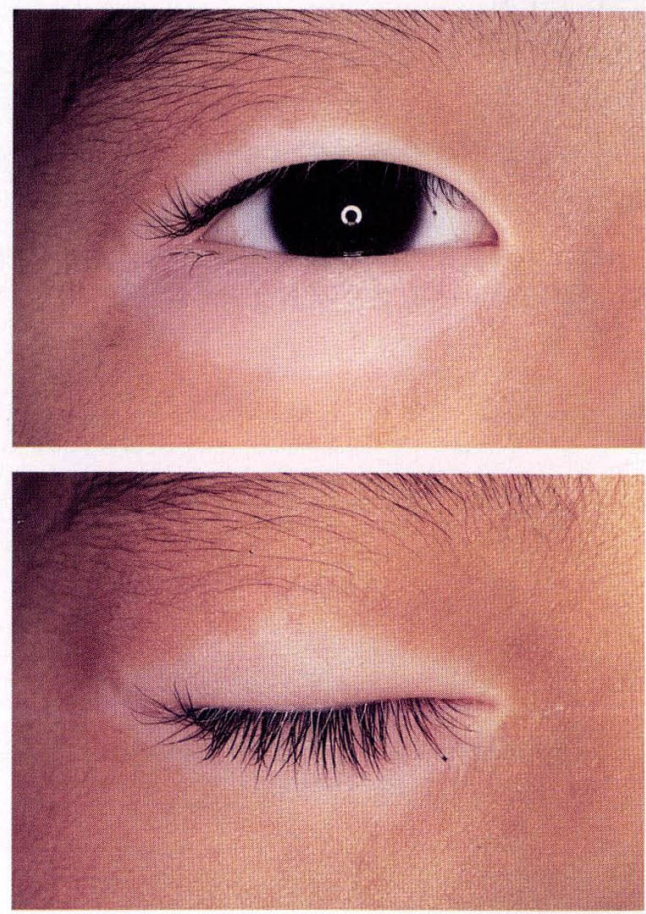

2. 弱視訓練後 右眼開瞼, 閉瞼

たため弱視治療は不要と判断し，それまで続け ていた健眼遮閉を中止した。右眼の眼瞼皮膚お よび睫毛が白くなっており, 左眼に異常はなか った。異常所見の範囲は瞼裂周囲で, 遮閉具の ガーゼ部分に一致していた。睫毛乱生および眼 瞼の炎症はみられなかった。受診前の経過を示 すと, 患児は 3 歳 6 か月で間歇性外斜視, 左眼 中心固視不良による斜視弱視の診断のもと，右 眼の終日完全遮閉と硫酸アトロピン点眼による 治療を受けた。患児は完全遮閉を嫌がり，瘙㾕

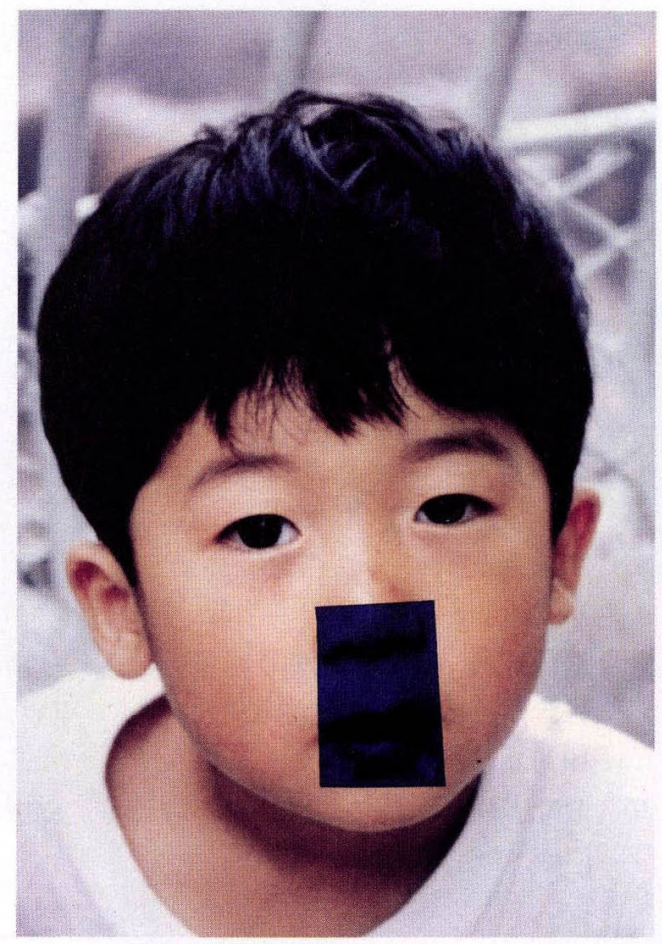

3. 弱視訓練前

感のため遮閉具の上から掻くことが多かったと いう。このころ, 遮閉具のガーゼに一致した眼 瞼皮虐に発赤がみられ，軟亳を塗布したという。 4 歳ころから, 右眼の眼瞼および睫毛の脱色が 認められたため, 硫酸アトロピン点眼を中止し, 完全終日遮閉のみを行った。 5 歳 6 か月ころか ら右眼の視力低下がみられたため時間遮閉に変 更して治療を継続していた。

考察および結論：皮虐の白斑は炎症および薬 剂などにより発生することが知られており， 1951年にグアノフラシン点眼薬による眼瞼白斑 および睷毛脱色の報告がある。今回の症例は, 白斑の範囲がガーゼ部分に一致していることか ら，その影響が大きいと考えられるが，色素異 常の発生機序は不明である。

\section{文献}

1) 清水小百合, 臼井千恵：健眼遮閉に用いる 各種遮閉具の比較検討. 日本視能訓練士協 会誌, $20 ： 159-164,1992$.

2 ）野間性道：白斑. Encyclopedia of me 
dicalsciences, $38: 114-116$, 講談社, 東京, 1983.

3) 堀 嘉昭：色素脱失症. 皮䖉病診察, 5： 595-602, 1983.

4 ）谷奥喜平：単純化学物質と皮虐障害. 244251 , 金原出版，東京， 1978.

5 ）船橋俊行, 小林明博: 炎症性皮虑疾患とそ の治療. 1-9, メディカルリサーチセン夕 一, 東京, 1976.

6 ) 宇山安夫：フラン誘導体. 日本眼科全書, 6 - $1: 108-109,1955$.

7 ）濱田稔夫：尋常性白斑, 皮周臨床, 33： 1093-1098, 1991.

8 ）福代良一, 西山茂夫他：尋常性白斑. 皮䖉 科診断治療大系 $4,82-83$, 講談社, 東京, 1985.

9 ）西野圭輔：顔面の尋常性白斑の治療，皮虐 臨床, $36 ： 931-935,1994$.
10）三島 豊：尋常性白斑. 45-58, 篠原出版, 東京, 1982 .

11) Duke-Elder. S, MacFaule. P. A: Vitiligo. System of ophthalmology, VOL. XIII, The ocular adnexa, 369-371, 1974.

12）白井千恵：弱視の視能矯正. 臨眼 $44: 1673$ $1676,1990$.

質問 小島とも总（京都桂病院） 1。一番 の原因は遮閉具によるものなのでしょうか?

2. 遮閉具のガーゼ部の漂白剤も原因と考え られますか。

答弁 1 ．白斑の範囲がのガーゼ部に一致し ていることから，その影響が大きいと考えられ ますが, 組織化学検査を行っていませんので詳 細は不明です。

2. 遮閉具のガーゼ部に使用されている漂白 剤も原因の一つと考えられます。 